\title{
A LINGUISTIC PICTURE OF THE WORLD AND EXPRESSION OF EMOTIONS THROUGH THE PRISM OF EXPRESSIVE LEXIS
}

\author{
DANKA SIROKA \\ danka.siroka@gmail.com \\ Comenius University in Bratislava, Slovakia
}

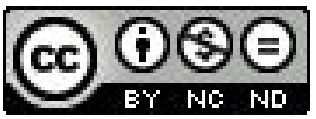

\begin{abstract}
This paper deals with expressive lexis, which is understood as the expression of emotions. Through this prism we would like to present a picture of the world which is formed by the opposites, emotional - rational. This picture would also present some examples of speech that is created in the mind as a result of man's preferences and values. The relation of language and mind, formation of a picture of the world on the basis of both linguistic and extralinguistic foundations, projection of emotions and assessments on language - all of these components are inspiring avenues and this paper trys to enlighten the basis of expressive linguistic inventory of the users of the Slovak language.

Key words: picture of the world, expressive lexis, emotions, stereotype, language, mind, assessment.

\section{„LANGUAGES ARE THE BEST MIRRORS OF THE HUMAN MIND“ (ANNA WIERZBICKA, 1994, S. 431)}

If we had to explain to a layman the term "the liguistic picture of the world," we would surely call it an infinite possibility of interpretations and perspectives based on liguistic and extra-linguistic human experience - of the individual, but also experience of a collective - a group of representatives of the cultural-social realities. The linguistic picture of the world has influenced the atmosphere of the Slavic (Russian, Polish and Czech) scientific schools in recent decades and it is also a product of ethnolinguistics which has become a current modern trend in thinking about language and it is closely linked to the cultural, anthropological, psychological, social, but especially to cognitive sciences. It is very important to bear in mind that as we are close to Slovak ethnolinguistics, so the current American school is a great source of new inspirations for us. In this paper we try to connect three basic themes: the linguistic picture of the world, expressive vocabulary, emotions and their oral expression.

The current scientific paradigm of linguistics is based on examination of the real meaning of language units and their anchoring in the human mind, which opens the door to trans-disciplinary examination of language and speech in the system of other, especially cognitive sciences. In connection to this we would like to emphasize the words of Irena Vaňková who highlights the symbolic function of language that "relates to transactions occuring in the human mind: it is about how
\end{abstract}


a person (as a speaker of certain language, the representative of other community and culture) perceives the reality, how a person categorizes it, how a person creates terms, what a person gives importance to, how a person judges - and how we can find out according to language" (Vaňková, 2010, p. 246). A person is an individual creature, perceives reality in his own perspective on the basis of which he/she separates experience and ranks the scale of values. We encounter new initiatives every day to which we must give a meaning, content and purpose. Here exactly you can see a close connection between semantic and cognitive structures (anchored in our minds) within the language. Next, we focus on clarifying cognitive-semantic relationships in the usage of language (with emphasis on expressive structures), as well as on the individual's world of values and its connection the evaluation of external stimuli.

Expressive words (expressive vocabulary) in Slovak lexical circles are the words which are usually subjects of emotions, affect and other aspects of human uncontrolled behaviour and thinking. We could differentiate thinking into rational and emotional (Dolník, 1987, p. 67), where rational thinking means intelectual processes of the mind dependent on cognitive knowledge of the world. When it comes to emotional thinking we can observe irrational component or emotional involvement. To both types of "thinking," evaluation of subjects is related. We are reminded that based on his study, Juraj Dolník $(1989$, p. 30) claims that learning about the world is connected with evaluation and experience, where the opposite objective versus subjective applies. Objective means that we know the world, entities, but we treat these entities subjectively and assess them on our own. This assessment is as usual on the axiological scale good - bad. The present evaluation scale works as the framework for uncovering the evaluation components hidden in the lexical semantic of a word. In following sections we would like to continue in terms of this thesis:

- "Values as an expression of the special relationship of man towards reality are identified by evaluative words." (Dolník, 1987, p. 70)

Such understanding of the semantics of the word indicates that this investigation goes beyond the frame of the system perception of lexical meaning. Under expressive vocabulary (and with this associated picture of the world served by such vocabulary) we understand expressions, which not by their formal side but by their meaning, are assigned to assessing expressions. These are words which by their lexical semantics are understood as contrast to semantically notional words (as comparison: darebák [villain] vs. zlý zamestnanec [poor employee]). We also understand them as emotional words containing an evaluation component (comparison: polarized pair super - kravina [bullshit]), as well as words which occur due to affective reaction to something or someone (e.g. swear words or reactions like fuj [ugh] - mňam [yummy]).

In the background of current trends in linguistics influenced by anthropology, psychology or cognitive sciences, we can assume that for full understanding and assignment of a word to certain concepts of perception its traditional lexicographical description isn't enough. It is because a certain word doesn't contain pragmatic meanings which include knowledge about how contextual factors influence linguistic 
thinking by using that word. For the meaning of the word, respectively of the picture of the world through the prism (expressive) words, it is necessary to feel also semantic features based on cultural components, social knowledge and psychological consciousness, and in that way on knowledge about the world and interactions with an extra-linguistic world. As an example we could mention for example the word auto [car]. We find out in dictionaries that it is „motor vehicle powered generally by an internal combustion engine" (SSSJ, 2006). But we don't find extra-linguistic facts in the dictionary - the need of a driving licence, the inability to drive a car under the age of 18, that the car runs on oil, gas or gasoline and so on. The dictionary meaning also doesn't give us stereotypical (possibly degrading and sexist) reactions of men drivers towards women drivers, how it is said for example in connection with a woman behind the wheel, you drive like a woman, you park like a woman and so on. A second example could be the word svadba [wedding]. Apart from several meanings listed in dictionaries (by KSSJ, 1997: ,a summary of ritual acts and habits by entering into marriage, the marriage ${ }^{\prime \prime}$ ) we associate this word with extra-linguistic knowledge, for example with the bride's white dress (in Slovakia), the veil, wedding cake, but also phrases such as (for example) marry someone for his money, marry someone because of love, or other reasons for "today's" marriage: pregnancy, the acquisition of citizenship and so on. These are facts anchored in the minds of language users and they work with them automatically, domesticated in the minds of language users, or whole language teams.

The linguistic picture of the world is dynamic and it answers the current needs of linguistic society and its users, it adapts to it and creates new stereotypes. Similar opinion was expressed by the well-known American linguist George Lakoff (2006) in his monograph Women, fire and dangerous things, which claims that "the definition knowledge is knowledge of fundamental characteristics of words and encyclopedic knowledge is knowledge of accidental words" characteristics" (Lakoff, p. 174). When a language user uses a certain expression in his communication, it doesn't mean that he/she thinks of its definition and meaning, but in context with this word he/she seeks other words, contents and contexts associated with it in the objective world, on the basis of good orientation in previous experience, or on the basis of his own intuition. As a conclusion we could say our research focus will go beyond the boundaries of traditional understanding of the word's meaning. It should reach the term "the linguistic picture of the world," which we understand as "a portrait of the reality without title to accuracy and fidelity, so it isn't a picture of real object" (Orgoňová, \& Bohunická, 2011, p. 7 according to Bartminsky). We also see the connection with ethno-linguistic definition of the meaning which should by „its content and structure of its components correspond to conscience of the average user of the language as holder of a culture“" (Orgoňová, \& Bohunická, p. 33). In this paper we are concerned with so-called naive picture of the world of expressive expressions and with capturing the constructing of expressions' world on the basis of the picture its users have.

Our viewpoints on the subject of the language picture of the world were encouraged by many other works of Slovak or foreign authors. A great inspiration for us are the papers of I. Vaňková. She can be described as a pioneer of ethnolingu- 
istics in the area of Czech linguistics. She was able to give an overall picture of new trends in current Slavic linguistics by her monograph What's in the heart, that's on the tongue (2005). We should also cite her other works, such as Pot full of speech (2007) or the whole series of the journal The word and the verbality (2010), thematically oriented to postulates of ethnolinguistics and issues of the language picture of the world, where she translated important contributions of Polish colleagues from Warsaw, Lublin into Czech, with whom I. Vaňková maintains important linguistic contacts. As our inspiration we should mention the Polish school (keeping in mind the personalities Jerzy Bartmiński, Renata Gregorczykowa, Anna Pajdińska, Ryszard Tokarski, Krystyna Waszakowa, as well as Anna Wierzbicka), and not omit domestic resources and names as J. Dolník $(2005,2010)$, or an interesting co-operation O. Orgoňová and J. Dolník, resulting into the publication Using the Language (2010). Inspirational and guiding was as well the process of fundamental concepts of ethnolinguistics in the work Lexikology of the Sloveak language (Orgoňová, \& Bohunická, 2011).

The Linguistic picture of the world, seen as mental awareness of words from a linguistic, cultural and social or psychological point of view, could be metaphorically described as a broad avenue with a number of small streets, and each of them is beneficial for the avenue, because it represents a new incentive for making the atmosphere of the avenue complete. Thus, the LPW rests on the platform of linguistics, but it cannot be outlined adequately without relevant pieces of knowledge of other disciplines. LPW is a product of global thinking about words, and it activates broader knowledge systems that are called lexical concepts (e.g. on the background of emotions) - J. Dolník (2010); A. Wierzbicka (1999); Vyvyan Evans \& Melanie C. Green (2006) with their theory of domains, and many other. Cognitivists claim that these are cognitive entities feeding the information ",behind the scenes" about the entity which we would not find out in a dictionary; this is the so-called mental cognition, concept. We know the meaning of the words hot and cold simply because our own tactile experience gives us the knowledge of the thermal system; otherwise we would not be able to understand these words. Similarly: without a visual "experiential complex" we would not recognize any colors, without the auditory one - any tones, without the olfactory one - any odors or smells; we would also be unable to give information about the right time if we did not know the temporal system, and so on. (examples by V. Evans and M. Green (2006) p. 230). Such systems for understanding expressions represent lexical concepts, "switched on" by the users of a language according to their communicative needs. Lexical concepts are therefore frameworks that are arranged into a larger network, while the lexical meaning is interpreted on their basis in a relation to one or more of the frameworks - lexical unit triggers an incentive to launch an experience and knowledge based inventory associated with a particular lexical concept which is closely related to the meaning of the given lexical units.

A similar theory was elaborated in the paper with a title Using the Language written by authors O. Orgoňová a J. Dolník (2010). Their ideas focus on the relation of linguistic expressions to the world, and in the foreground, there is the point that "a certain segment of the world corresponds to a certain segment (a 
certain field) of linguistic expressions, in which the understanding of the given segment of reality is anchored" (Orgoňová, \& Dolník, 2010, p. 52). We do not master linguistic expressions independently, without associating them with a whole group of other expressions, with which the given expression is more or less closely combined. The selection of meanings by conceiving the message to be communicated then indicates good orientation in the linguistic inventory of a language user (for example, when choosing synonyms). From this we derive conclusions that in certain situations (contexts), language users can choose certain units of the language inventory which they deem appropriate to the given linguistic situation. This means that we should speak not only of lexical fields, but of language fields. That also includes stylistic rules and pragmatic effects associated with the addressee of such utterance.

In our research, we focus on the linguistic picture of the world through the prism of expressive vocabulary which is determined by emotional factors. Emotions are understood according to Milan Nakonečný $(2000$, p. 7) as a component of instinct, while one of their functions is evaluating situations and preparing to manage them physically (physiological and social needs of an individual, such as hunger, love - hate, etc.). With the development of humanity, emotional stimuli increased through ideas and values given by the culture and naturally; we cannot but mention their most important - psychological - component, which also affects the communicative activity of language users. This paper gives no space for dwelling upon the natural vs. learned essence of emotions (instinctivism vs. behaviorism, cf. e.g. Erich Fromm (1997, p. 14 - 23), nor for creating a picture of the world on the basis of specific emotions (e.g. LPW of fear, A. Wierzbicka (1999), also Cliff Goddart (2008) and his paper on expressing warning and sensitivity in Malaysian culture, and many other) and even for comparing the ways of expressing emotions in different cultures (e.g., the so-called. Japanese emotion "amae" mentioned in many studies, such as Rom Harré \& Grant R. Gillett (2001, p. 167)). Although all studies focused on the relation of emotional system to the linguistic system are interesting to us, we systematically focus only on a specific communicative activity by users in emotionally strained situations. Emotions in our view should be seen as a multidimensional phenomenon, and their "linguistic study, apart from examination of words with an emotional evaluative component, must also include grammatical patterns, idioms, comparisons, metaphors" (Wierzbicka, 1999, p. 30), as well as other markers such as synonymous expressions conditioned by subcultures, intonation in communication or prejudices and stereotypes conditioned by tradition or cultural and social rules, etc. (more in the second part of the paper).

At this point, it would be apt to pay attention to the recipient, the addressee, who interprets the given language construct presented by the sender. In interpretative constructs, addressee's thought functions by analogy (Lenk 1994, according to Orgoňová, \& J. Dolník, 2010, p. 148 and Dolník, 2010, p. 41). It identifies communicative situations according to them, and on their basis performs evaluation of communicative situations and attributes further characteristics to them (degree of importance, regularity, etc.). Another part of an interpretative construct is an axiological concept that each language user disposes of and uses to evaluate the 
messages communicated - basing on the lexical material, they can assess the situation at hand as emotionally strained. The emotional state of language users manifests itself in an array of lexical concepts. "The analysis of linguistic expressions as carriers of these concepts is a way to the cognition of emotional and affective objects constructed through language in the given cultural community" (Dolník, 2010, p. 42).

\section{EXPERIMENTAL RESEARCH PROBES AN EMPIRICAL PROCESSING OF THE PICTURE OF THE WORLD ON THE BASIS OF THE RESEARCH MATERIAL OBTAINED}

Research orientation in the present paper is based on the introductory pillars. We are aware of the difficulty level of research connected to the simulation of the linguistic picture of the world through the prism of a certain language, and it should thus be said that our research is still in its intial stage. It is diffiult, from the point of view of the creator of the research method in particular, to detect ways in which people use expressive vocabulary giving to it preference over notional lexicon, and reasons why they resort to such lexical units, structures and phrases. We carried out our research on the association of mind and language in the form of a test. For the purposes of this paper we choose one of the five thematic fields that proved to be the most appropriate to us as the respondents explained the content (not the meaning) with such units that are characterized by a certain degree of expressiveness, or are marked by emotional experience embedded in them. We hoped to learn from the respondents what idea of the object described they have, or whether they provide the linguistic picture of the world according to their assessment of an extra-linguistic realm. We perfomed the test with each respondent personally, we talked with all of thea and answered their questions (which abounded in course of the research). Interestingly, almost every respondent asked, what the correct answer was - by such questions we had to direct the respondents, affirming that the point was not to check their knowledge but to find out what the respondents would do first if they talked about such an object, read about it, or used it themselves.

At this stage of the research, it is not possible to talk about quality probes, because:

1. with every test performed we encountered complications (for example, respondents did not understand the task and so on).

2. We focused on a single group of people with similar interests, attitudes and social status. Respondents are aged 23-28 years, all of them are employed, some of them are studying alongside (majoring, above all, in economy and mass media). All respondents come from Bratislava (Slovakia), they are sports-inclined and their views are normal ${ }^{1}$ in relation to current social trends and ideals.

In this meaning, normality is understood as "corresponding with what conforms to a certain idea of what the entity of a certain kind should be like at baseline with regard to its acepting perception" (Klaus P.Hansen 2000, quoted according to O. Orgoňová - J. Dolník 2010). Within this relations, we understand normality as behavior, thinking and acting that are not different from the behavior, acting and thinking of the other members of the community. 
3. Our research unit consisted of only twenty respondents so far. Although this number is not sufficient for relevant research, the performed pre-researched provided this work with first incentives towards corrections necessary to optimize the assignment, as well as the first signals of answer anticipation. The material received is a good sample for revealing a single view of the world from the standpoint of a relatively homogeneous group of young people (within the framework of diverse perspectives that correspond to differentiated social groups).

The most extensive as well as expressive research material emerged in the sphere of cars and driving. The respodents were given the following expressions in these short sentences.

\section{I bought a new car. \\ Driving is something I am best at.}

Subsequently, basing on their own experience, they had to fill in the spheres ${ }^{2}$, by means of which we wanted to reflect the thinking of our respondents. What picture of a car as a means of transport and of driving a vehicle have our respondents? A lot of stereotypes are associated with driving, such as a general (a priori) social idea that men drive better than women - almost all respondents answered the question How do I call, define other traffic participants (other cars, drivers, pedestrians, ...) and the question Phrases that I normally associate with driving - a car with sexist overtones (e.g. Jáaj, stará pani za volantom, už nech sú Vianoce, aby si ostala doma [Aw, an old lady behind the wheel, let it finally be Christmas time so that you staye home], Zas blondina [A blonde again], Žena!, Ženská!, Ženy by mali varit', žehlit' a nejebat' sa v aute [Woman! Female! Women should cook, iron and not fool around in a car], Blondina za volantom rovná sa katastrofa [A blonde behind the wheel equals disaster], Ženy nevedia parkovat' [Women don't know how to park], Hen blondinečka - auto si určite zaslúžila [Here comes a little blonde - you definitely earned your car], Načo máš blinker, hlavne že sa machlís [Why do you need a blinker when you are so busy with your make up] and other, vulgar names in the first place). How do these stereotypes emerge? Why should men be better drivers than women? How does such strong egocentrism consolidate itself in the human mind? These statements are the result of conceptualization of schemes by language users who conceive their picture of the world on the basis of generally accepted (albeit distorted, simplified and biased) statements in a certain community.

The sphere of driving a vehicle and language content connected with it was selected on the basis of general stereotypes, that is, judgements transferred from one category of people to the other (for example, generational ones as well)

\footnotetext{
2 The sphere of car and driving consisted of further open questions, through which we got our own specification of the given expression from the respondents. The questions were as follows:

1. Synonyms (expressions with the same or a similar meaning, can be non-literary a well) -

2. How do I call, define other traffic participants (other cars, drivers, pedestrians, ...) -

3. Stages that I often associate with driving / a car -

4. Other relevant expressions that I use in connection with a car / driving (all I have to do to make the car go)-

5. Provide all synonyms from task 1 with at least one example sentence, please -
} 
before such judgements are verified by personal experience. Note that drivers often find themselves in tense situations, that they happen to be not quite critical towards their driving skills, they swear at other traffic participants, are selfcentered and so on. This brings them into emotionally strained states, whereby they express their anger through language. According to our research, insults and curses are often targeted at those drivers whose registration plate show that they come from another town, so they know the place only slightly, violate traffic rules, slow traffic down etc.

Our research mapped frequent use of the phrase $C P$, cépéćkár (a person from another town; the word originated from the term "cezpolny" ["cross-country"] and is its graphic and phonic abbreviation with a derivatinal affix added), which once again demonstrates drivers' chauvinism (e.g. from our research: sedlák [a peasant], cépečkár [CP], hurá cépečkári [hooray CPs], táahajte odkial' ste prišli [pull back to where you came from], vitajte v meste [welcome in town], cépéćkari chod'te domov [CPs go home], Mad'ar [a Magyar], etc.). Apart from these, the tests revealed other phrases on the basis of which we shape conclusions on drivers' opinion about other traffic participants. For example, they defined pedestrians as darcovia orgánov [organ donors], nesmrtelní l'udia [immortal people], pešiak [foot-soldiers]; quite frequent was also a slightly scornful view of drivers who have not purchased their car out of their own pocket (e.g.: but they have a car that could feed Africa, you earned your car for sure, employment called son, employment called daughter and other), knowing nothing about the driver's source of money for the car, or whether the car actually belongs to them, etc. All of our respondents have a driving license and the majority of them own a car and use it daily, therefore our sample can be considered competent (having their own driving experience of traffic situations) in the car and driving subject area. We assume that the use of expressive lexical inventory while driving is not just the domain of young drivers. It should be pointed out that in course of completing the test we did not incite the respondents to use expressive words or insults, we only asked from them denominations of other traffic participants. The picture of driving through the prism of linguistic inventory of young people seems to be a place for airing emotions, feelings and opinions by means of expressive vocabulary. This way a general view is reproduced and strengthened that men are better at driving than women, that someone who has an expensive car certainly got it as a gift from their father or boyfriend, and that the city is no place for commuters with strange number plates. The driver (as a language user, apart from all the rest) categorizes other drivers on the basis of these general views and stereotypes, showing the tendency to overlook his faults, but come up with a biting comment on others' mistakes. Here, for example, we find confirmation of a proposition from the introductory part of our paper - individuals evaluate the situation using an inventory of expressions that contains an emotional (as far as sexist and self-centered, from what we have seen,) component and at the same time expresses theur attitude towards the fact under evaluation by means of it.

An interesting source of expressive vocabulary was the first question of the thematic sphere in which we asked the respondents to give synonyms for the 
terms car and driving. Although the question was posed as a quantitative one and we impelled the respondents to cite as many synonyms as possible, we were particularly interested in the first association related to cars and driving. We consider these two expressions to be unmarked, neutral with respect to synonyms, which are marked. Surprisingly, as many as thirteen respondents, which is more than half of them, gave a slang word kára (cart) as the first synonym (from other terms, the most frequent were autiak, fáro, mašina, šrot), thus the respondents sought synonymous expressions mainly in the slang language register.

The sphere described was a rich source of information for us. We were very surprised to find out that all the respondents seemed have automatically seated behind the wheel while describing traffic situations. Interestingly, all respondents were unilaterally "ill-tempered", so they a priori evaluated only bad aspects of road transport. They thus described the situations mainly from the negative point of view (with which the occurrence of swear-words, vulgarisms, etc. on the surface expressive level is connected), this, nevertheless, only indicates the prototypical/ dominant picture of the world that the drivers dispose of. Responses were detailed and creative, therefore we would like to add to the future research a questions for grasping the profile of respondents' broader mental field based on their experiences from a balanced segment of reality - including both positive and negative aspects. We bear in mind such questions as, for example: why do you prefer driving instead of using public transport, when do you enjoy driving, and when you do not, or to describe a particular traffic situations, and ask the respondents how they would react, and so on.

In our research, we have not yet found space for questions on perlocutive perception of expressive structures at the other end of the communication channel, by the addressee of an utterance, which will constitute one of the parts of our subsequent research. The probes that we performed on the basis of the present study proved to be an appropriate method of obtaining material. The respondents enjoyed taking the test, which ensured effective cooperation with the researcher and yielded necessary results and varied language material. In particular, the first question, the subject of which was focused on daily activities, demonstrated to us their interest and enthusiasm, therefore it would be advisable to choose for a further research such evaluating expressions that are inherent in their daily life (for example, such thematic spheres as jealousy, envy, phlegmatic, and others) and thus give the linguistic picture of the world based on the evaluative expressions associated with extra-linguistic factors (such as the image of anger in the language - G. Lakoff 2006, the linguistic picture of fear - A. Wierzbicka 1999 or K. Waszakowa and her Conceptualization of pain in the Polish language 2010, and many other). The linguistic picture of the world reflects not only traditional elements of language (phrases, proverbs, sayings) which are inherent to the whole community, but also ideolectic non-conventional combinations, and, last but not least, extralinguistic facts, that is, those facts that come from a different spheres of knowledge about the world (according to A. Pajdińska \& R. Tokarski, 2010). 


\section{CONCLUSIONS}

Our focus - presenting the linguistic picture of the world through the prism of expressive vocabulary - will also be linked to the emotional statements by the language users in future research. Emotional speech is an integral part of the mental equipment of standard language users. The research will proceed with the idea that ,the mind is, in a sense, a social structure that attests to the fact that terms occur in discourse and shape the way we think. ... Therefore, the way in which we conceptualise the world around us depends on the available terms that we have within our discourse and experience related to it" (Harré, \& Gillet 2001, p. 50).

In subsequent stages of our research, we will also pay attention to the recipient's view of expressive language. One of the suggestions could be to explore expressiveness in the extremeties of fun and joy - outrage and preoccupation, as well as the markedness of expressive units in statements as intentional deviations from conventional forms, on the pragmatic level above all. The expressiveness of an utterance in media entertainment was observed by A. Bohunická (2009), and basing on the ideas of František Miko (1965), expressiveness in an utterance means a specific move of the author, who "shapes the object in a strange, unusual way, thus reflecting subjective occupation, evaluation or interpretation of the given fact" (Miko, 1965, p. 17). F. Miko sees emotionality only as a certain degree of expressiveness. We believe that the ideas of this inspirational author should currently be further developed and elaborated on, and therefore our research focus reaches beyond investigation into the relationship author - creation of a peculiar utternce, or evaluation of the situation, towards the emotional base of expressive statements. We would also like to show expressiveness in other outlines that different from those given in an old, but the only monograph of the kind within our reach, that positions expressiveness witin the structural typology distinguishing between inherent, adherent and contextual expressiveness (Zima, 1961). At present, the level of research exceeds the boundaries of structural linguistics and opens the door for interdisciplinary investigation into expressiveness as an emotional component of our thinking and its transformation into a linguistic and speech statement. Other suggestions for subsequent research were borrowed in course of studying the interdisciplinary anthology The Verbal Communication of Emotion (2008). These include for instance:

1. Sharing emotions with people - surprise, anger, joy or sorrow, we often feel the need to verbally express what emotional state we are in (Bernard Rimé, Susanna Corsini \& Gwenola Herbette) because we feel fantastic or, on the contrary, depressed and need comforting. Suitable material could be collected from internet forums, because nowadays it is very common for young people nowadays to share their emotions and moods on social networks.

2. The second pillar of the research could be represented by a specific language form used in describing an emotional experience - use of notional or figurative language (Raymond W. Gibbs, John S. Leggitt \& Elisabeth A. Turner), as well as the speed of spoken speech, its intensity and so on. An 
interesting research question would be the use of multiple acquired registers of the Slovak language, and similar.

3. Another capture point might be constituted by observing behavior regulation, the way communication modifies emotions (calms down vs. stirs up), and on the other hand - how emotions modify communicative behavior and discourse direction (Reinhard Fiehler).

4. An interesting point is also a modern tendency for the need to use emoticons and smileys in Internet within non-verbal communication for finalizing the emotional situation in which information is presented (Susan R. Fussel).

Research of this type will probably be difficult, but we believe that namely the creativity of respondents in the qualitative research is the right source of the linguistic picture of the world. A. Pajdińska and R. Tokarski argue that there is a two-way relation between the linguistic picture of the world and creative texts - "not only does the conceptual structure stored in the given language reflect in the texts, but vice versa as well: these texts may be useful for establishing the linguistic picture of the world. Thanks to them we can penetrate to the ideas of the world that are "embedded" in the language more quickly and efficiently than through analyzing systematized, conceptualized facts" (Pajdińska, \& Tokarski 2010, p. 295 - 296).

The relation of language and mind, formation of the picture of the world on the basis of both linguistic and extralinguistic foundations, projection of emotions and assessments on language - all these constitute are inspiring realms for us that we are trying to bring closer on the basis of expressive linguistic inventory of the users of the Slovak language.

\section{REFERENCES}

Barmiński, J. (1996). Stownik stereotypów i symboli ludowych [The Dictionary of Folk Stereotypes and Symbols] (1st ed.). Lublin: Kosmos.

Bohunická, A. (2009). Expresívnost' v mediálnej zábave. [Expressiveness in Media Entertainment] In: V. Kováčová (Ed.), Aspekty literárnovedné a jazykovedné II [Aspects of Literary Science and Linguistics II] (pp. 86-97). Ružomberok: Katolícka univerzita v Ružomberku.

Buzássyová, K. (2006). Súčasný slovník slovenského jazyka A - G. [The current dictionary Slovak language A - G] (1st ed). Bratislava: Veda.

Dolník, J. (1987). Hodnotiace slová v slovenčine [Assessment Words in Slovak Language] In: J. Mistrík (Ed.), Studia Academica Slovaca [Slovak Academic Studies] (pp. 67-83). Bratislava: Alfa.

Dolník, J. (2010). Jazyk, človek, kultúra [Language, Human, Culture] Bratislava: Kalligram.

Dolník, J. (1989). Lexikálne vyjadrenie emocionálneho hodnotenia. [Lexical Expression of Emotional Assessment] Slovenská reč, (54, 1), 30-39.

Dolník, J. (2005). Jazykový systém ako kognitíona realita [Language System as a Cognitive Reality] In: J. Rybár, V. Kvasnička \& I. Farkaš (Eds.), Jazyk a kognícia [Language and Cognition] (pp. 39-83). Bratislava: Kalligram.

Evans, V., \& Green, M. C. (2006). Cognitive Linguistics: An Introduction. Edinburgh: Edinburhg University Press.

Fromm, E. (1997). Anatomie lidské destruktivity [Anatomy of Human Destructiveness]. Praha: Nakladatelství Lidové noviny.

Fussel, S. R. (2008). The Verbal Communication od Emotions. Interdisciplinary Perspectives. In: S. R. Fussel (Ed.). Hove, East Sussex: Psychology Press.

Goddart, C. (2008). Explicating Emotions Across Languages and Cultures: A Semantics Approach. In: S.R. Fussel (Ed.) The Verbal Communication of Emotion. Interdisciplinary Perspectives (pp. 19-53). Hove, East Sussex: Psychology Press. 
Harré, R., \& Gillet, G. R. (2001). Diskurz a mysel' [The Discursive Mind]. Bratislava: IRIS.

Kačala, J. (2003). Krátky slovník slovenského jazyka [Short Dictionary of Slovak Language] (4th ed.). Bratislava: Veda.

Lakoff, G. (2006). Ženy, oheň a nebezpečné věci. [Women, Fire, and Dangerous Things] Praha: Triáda.

Miko, F. (1965). Expresívnost' výrazu v umeleckej próze [Exressiveness of Expression in Prose] In: F. Miko (Ed.) Jazykovedné štúdie VIII [Linguistic Studies VIII] (pp. 5-41). Bratislava: SAV.

Nakonečný, M. (2000). Lidská emoce [Human Emotions]. Praha: Academia.

Orgoňová, O. \& Bohunická, A. (2011). Lexikológia slovenského jazyka [Lexicology of Slovak Language] Bratislava: Stimul.

Orgoňová, O. \& Dolník, J. (2010). Používanie jazyka [Using the Language]. Bratislava: Univerzita Komenského.

Pajdińska, A. \& Tokarski, R. (2010). Jazykový obraz světa a kreativní text [Linguistic picture of the world and creative text] Slovo a slovesnost, $(71,4), 288-297$.

Vaňková, I., Nebeská, I., Saicová-Římalová, L. \& Šlédrová, J. (2005). Co na srdci, to na jazyku [What's in the Heart, that's on the Tongue]. Praha: Karolinum.

Vaňková, I. (1999). Kognitioně-kulturní inspirace z Polska [Cognitive-cultural Inspiration from Poland] Slovo a slovesnost, (60, 3), 214-224.

Vaňková, I. (2007). Nádoba plná řči [Pot Full of Speech]. Praha: Karolinum.

Vaňková, I. (2010). Úvod: na cestě ke kognitivní (etno)lingvistice. [Introduction: Towards a cognitive (ethno)linguistics] Slovo a slovesnost, (71, 4), 245-249.

Waszakowa, K. (2010). Konceptualizace bolesti v češtině: př́spěvek ke srovnávacímu výskumu [Conceptualization of Pain in Polish: A Contribution to Comparative Research] Slovo a slovesnost, $(71,4)$, 298-309.

Wierzbicka, A. (1994). Cognitive domains and the structure of the lexicon: the case of emotion. In: L.A. Lawrence \& S. A. Gelman (Eds.) Mapping the Mind: Domain specificity in cognition and culture (pp. 431452). Cambridge: Cambridge University Press.

Wierzbicka, A. (1999). Emotions Across Languages and Cultures: Diversity and Universals. Cambridge: Cambridge Universal Press.

Zima, J. (1961). Expresivita slova v současné čšstině [Expresiveness of Words in Current Czech Language]. Praha: Nakladatelství ČSAV. 